\title{
PENGEMBANGAN STRATEGI MOTIVASIONAL PADA MATA PELAJARAN PKN DALAM MENINGKATKAN PRESTASI DAN MOTIVASI BELAJAR SISWA SMP
}

\author{
Marthinus Mandagi \\ Jurusan Administrasi Negara, Fakultas Ilmu Sosial, Universitas Negeri Manado \\ Jalan Tondano, Manado Sulawesi Utara 95618 \\ Email : marthinusmandagi@yahoo.com
}

\begin{abstract}
ABSTRAK
Penelitian ini bertujuan untuk mendeskripsikan: prestasi belajar siswa dalam matapelajaran PKN pada enam kecamatan di 3 Kabupaten yang ada di SULUT; motivasi belajar siswa SMP pada 6 kecamatan di 3 kabupaten Minahasa; strategi pengelolaan motivasional yang dilakukan guru-guru SMP pada 6 kecamatan di Kabupaten Minahasa; dan mengembangkan model rancangan motivasional untuk matapelajaran PKN. Rancangan penelitian ini terdiri dari dua jenis, yaitu: (1) deskriptif prestasi belajar melalui survey dan (2) pengembangkan model Pembelajaran motivasional Matapelajaran PKN SMP. Instrumen yang digunakan untuk memperoleh data motivasi belajar siswa dan strategi motivasional disusun oleh tim peneliti.Subjek penelitian : siswa SMP di enam kecamatan di Kabupaten Minahasa yang mewakili kecamatan yang besar, sedang, dan kecil yaitu siswa serta guru bidang studi PKN di SMP. Untuk uji ahli terdiri atas Ahli Isi, Media, dan Ahli Rancangan.Analisis data yang dipakai untuk memperoleh data motivasi belajar siswa, strategi motivasional yang dilakukan guru adalah analisis deskriptif. Sedangkan untuk mengembangkan model adalah analisis deskriptif berbentuk prosentase kesepakatan di antara para ahli dan subyek penelitian.. Hasil penelitian ini akan dapat digunakan secara langsung oleh perancang pembelajaran yang berupa pedoman dan langkah-langkah dalam merancang pembelajaran yang memperhitungkan aspek motivasi. Sedangkan bagi guru akan diperoleh preskripsi dalam hal bagaimana menerapkan rancangan motivasional dalam pembelajaran PKN Di SMP.
\end{abstract}

Kata kunci: prestasi belajar siswa, motivasi belajar, strategi mengelola motivasi, model rancangan motivasional

\section{DEVELOPMENT OF MOTIVATIONAL STRATEGY FOR CIVIC EDUCATION LESSON TO IMPROVE ACHIEVEMENTS AND MOTIVATION OF JUNIOR HIGH SCHOOL STUDENTS}

\begin{abstract}
This study aimed to describe; student achivement in PKN lesson in six distric in three subdistric in North Sulawesi: Junior high school students' motivation in 6 district in 3 Minahasa subdistrict; motivational managent strategies perfomed by teacher of Junior high school in 6 districts in Minahasa; and developing a model of motivation design for PKN lesson. The design of this study consisted of two type, namely : (1) descriptive of study achievement through survey and (2) learning model of motivational lesson development for PKN lesson in Junior high school. The instrument used to obtain data on student' motivation and motivationan strategies compiled by a team of research. The subject of the research was : Junior high school student in six district and teacher of PKN in Junior high school. For the expertise test was consisting of experts for Cotent, Media. And design expert. Analysis of the data used to obtain data on students' motivation, motivational strategies that teachers undertake was descriptive analysis. As for developing a model is descriptive analysis in the form of precentage of agreement among experts and the subject of the research. The result of the study will be used directly by the intructional designer in the form of guidelines and steps in designing the learning that takes into account the aspects of motivation. As for the teacher to be obtained prescriptions in terms of how to implement the design in the learning motivational of PKN in Junior high school.
\end{abstract}

Keywords : Student achievemend, motivation to learn, strategies to manage motivation, motivational design model 


\section{PENDAHULUAN}

Berbagai penelitian yang berhubungan dengan bidang studi PKn telah dilakukan para ahli bidang studi PPKn, psikologi pendidikan, dan pembelajaran. Laporan penelitian Kramer (1978) dan Kantowski (dalam Fennema, 1981) menyatakan bahwa rata-rata hasil belajar pemecahan masalah pebelajar masih rendah. Thornton, Tucker, Dossey dan Bazik (1983) serta Marshall (1984) menemukan bahwa hasil belajar ilmu-ilmu sosial lebih rendah daripada hasil belajar pemahaman konsep matematika dan komputasi. Hasil penelitian National Assessment of Educational Progress (NAEP) di Amerika (Carpenter dkk. dalam Fennema, 1981) menyatakan bahwa jumlah pebelajar yang dapat menjawab dengan benar soal komputasi sebesar $70 \%$, sedangkan untuk memecahkan suatu masalah hanya sebesar 20\%. Demikian pula temuan berbagai penelitian di Indonesia bahwa PPkn merupakan matapelajaran yang kurang menarik di antara mata pelajaran lainnya di sekolah.

Untuk mengatasi masalah tersebut, telah banyak tindakan dalam usaha meningkatkan kualitas pendidikan dan pembelajaran, namun demikian, kualitas pendidikan di Indonesia saat ini masih rendah. Sementara sumber-sumber belajar seperti buku teks begitu banyak tersedia, bahkan di beberapa sekolah buku teks dipinjamkan kepada siswa. Selain itu, dengan meningkatnya kesejahteraan bangsa, rasanya sudah tidak dapat dipercaya bahwa siswa sekarang kualitasnya rendah diakibatkan oleh tingkat kecerdasan, keterbatasan sumber-sumber dan fasilitas belajar dibandingkan dengan siswa di masa yang lalu. Bertambah baiknya keadaan ekonomi, kesehatan, dan gizi masyarakat sekarang, mestinya kualitas pendidikan dan pembelajaran dapat lebih meningkat.

Sejumlah strategi pembelajaran telah coba dilakukan dan sebagian berhasil, namun sebagian gagal mengefektifkan pembelajaran. Kegagalan tersebut antara lain karena aspek mengefektifkan pembelajaran, yaitu merancang pembelajaran yang dapat memotivasi siswa, belum dilakukan dengan baik. Seperti diungkapkan Ardhana (1994) bahwa salah satu sebab rendahnya kualitas pendidikan tersebut yaitu motivasi belajar siswa rendah. Siswa tidak suka membaca dan belajar di rumah, tidak berpartisipasi dalam kegiatan belajar, tidak mengerjakan pekerjaan rumah, kurang gairah belajar, menyontek pekerjaan teman. Bahkan banyak mahasiswa lebih suka memanfaatkan jasa orang lain untuk mengerjakan tugas-tugas pembelajaran dan sejenisnya. Demikian pula menurut Keller (1983) Jika masih banyak pendekatan pembelajaran yang nampaknya hanya membuat siswa terus sibuk di kelas, tetapi sebenarya hanya membuat siswa menderita selama mengerjakan tugas-tugas di kelasnya, tidak pernah habis dan tidak tahu untuk apa mereka mengerjakan tugas tersebut. Tidak heran bila pemahaman tentang bagaimana dapat membangkitkan dan mempertahankan minat siswa dalam belajar masih jauh tertinggal. Karena itu bila anak bosan, cemas, terganggu, dan tidak terfokus terhadap pembelajarannya, maka hal ini menunjukan bahwa strategi motivasi tidak berhasil.

Strategi pembelajaran yang memasukkan tujuan-tujuan kognitif dalam pembelajaran masih berada dalam taraf awal dibanding rancangan 
pembelajaran lainnya yang sudah berkembang. Karena itu strategi motivasional menjadi penting sekali sebagai usaha untuk mendorong seseorang mengintegrasikan faktor motivasi ke dalam pembelajaran. Jika strategi motivasi diterapkan dalam pembelajaran diharapkan pembelajaran akan efektif, karena pembelajaran tersebut menjadi lebih bermakna dan lebih menarik bagi siswa. Keller (1987) juga menyatakan bahwa memasukkan unsur motivasi dalam rancangan pembelajaran belum mendapat banyak perhatian. Ia mencoba mengetengahkan unsur motivasi agar pembelajaran lebih menarik dan tidak hanya memperhitungkan aspek efisiensi dan efektifitas saja. Penelitian yang dilakukan Cooley \& Lohness (1976) menunjukan pentingnya motivasi, dan perhatian terhadap aspek motivasi dapat menolong dalam memahami sifat-sifat khusus dari motivasi berkaitan dengan performansi, dan yang berkaitan dengan vaeriabel-variabel non kognitif seperti kualitas pengalaman di sekolah.

Motivasi merupakan aspek yang selalu ingin diketahui oleh para guru untuk menjawab pertanyaan mereka sendiri tentang apa yang menyebabkan seorang siswa bertindak dalam satu cara tertentu (Elliot et al. 1996). Motivasi itu sendiri telah menjadi konstruk sentral dalam penelitian psikologi dan pendidikan selama 30 tahun terakhir (Weiner, 1990). Hal ini mengindikasikan bahwa faktor motivasi terus menjadi perhatian baik oleh praktisi (guru) maupun oleh para peneliti. Karena itu tidak ada definisi tunggal yang bisa mendefinisikan motivasi dengan sempurna. Ford (1992) melihat motivasi sebagai sebagai aspek yang terdiri dari dari tiga komponen yang saling berhubungan: personal goals, personal agency goals, dan emotions. Goals merujuk pada apa yang siswa temukan bermakna secara pribadi bagi dirinya. Goal yang telah ditetapkan oleh guru menjadi motivasional hanya jika goal tersebut diadopsi oleh siswa sebagai personal goal baginya.

Personal agency beliefs merujuk pada beliefs para siswa bahwa mereka memiliki kemampuan untuk mencapai goals. Beliefs siswa haruslah beliefs yang realistik, berdasarkan pertolongan guru dalam mengidentifikasi cara-cara untuk mencapai tujuan (goals). Misalnya siswa yang memutuskan mengikuti kontes atau perlombaan dalam berbagai bidang studi, motivasinya didasarkan pada beliefs bahwa hal ini bisa dilakukannya. Bila ditambah dengan keinginannya untuk kerja, dia akan merasa lebih confident karena dukungan gurunya berupa bimbingan untuk melatih soal-soal matematika yang sulit dan kesediaan guru mengetesnya. Selanjutnya guru sadar akan peran emotions dalam arousing behavior. Bagaiama rasanya saat guru mencapai tujuan dari sesuatu yang anda kerjakan dengan susah payah. Guru akan merasa senang (feel good); reaksi emosional subyektif guru mencerminkan tingkat kesuksesan atau kegagalan yang dibayangkan telah dicapai. Siswa akan bereaksi dengan cara yang sama: mereka akan merasa senang dan merasa berkompeten ketika mereka berhasil mencapai tujuan. Singkatnya, dari penjelasan yang diperoleh, motivasi dapat didefinisikan motivation arouses, sustains, directs, and integrates behaviors (Elliot, 1996). Bila guru termotivasi, atau ketika guru mengamati bahwa siswa termotivasi, guru biasanya dapat menemukan 
sumber motivasi tersebut. Suatu tindakan dalam diri guru atau siswa untuk menghasilkan satu jenis tingkah laku tertentu yang bertahan pada satu level intensitas diarahkan pada satu tujuan yang jelas.

Dari definisi di atas, jelas motivasi memainkan peran penting dalam membuat orang ingin tahu (curious) dalam pembelajaran. Aspek motivasi tidak hanya secara eksplisit masuk dalam pendekatan pembelajaran yang telah dilakukan oleh beberapa pakar, tetapi juga dimasukkan dalam istilah-istilah yang lebih umum seperti aptitude, reinforcement atau feedback, dan yang lain masih memandang tidak penting aspek motivasi dalam belajar. Namun, secara umum motivasi dikenali sebagai satu elemen dalam model-model yang sudah ada (misalnya, Bloom, 1976; Cooley \& Lohnes, 1976; Gagne, 1977; Reigluth \& Merrill, 1979). Sayangnya berbagai prosedur mempengaruhi motivasi belum pernah ditampilkan secara rinci dan tepat untuk memudahkan perolehan konsep.

Masalah dalam pengembangan dan pengimplementasian pendekatan sistematik rancangan motivasional terletak pada pendekatan tradisional dan definisi yang digunakan para perancang pembelajaran bahwa tujuan pembelajaran adalah untuk merancang pembelajaran menjadi lebih efektif dan efisien. Tujuan ini mengenyampingkan dengan mudah kepeduliaan khusus terhadap motivasi atau yang kita sebut sebagai aspek kemenarikan yang memberikan rasa fun.

Asumsi-asumsi yang diketahui selama ini menyatakan bahwa bila pembelajaran memiliki kualitas yang baik maka motivasi akan otomatis bekerja. Sayangnya hal ini tidaklah benar sepenuhnya. Bila dikaji lebih jauh, pembelajaran yang berkualitas itu secara umum mengacu pada hasil belajar yang lebih baik per unit waktunya dibandingkan dengan berbagai metode pembelajaran lainnya (Keller, 1983).

Hal lain yang menarik, motivasi merujuk pada ukuran dan arah dari tingkahlaku. Singkatnya, motivasi merujuk pada pilihan-pilihan untuk mendekati ataukah sebaliknya menghindari pengalaman atau tujuan-tujuan tertentu, dan merujuk pula pada tingkat effort (usaha) seorang individu untuk coba dilakukan. Dengan demikian, motivasi dipengaruhi oleh karakteristik eksternal dan internal sesorang. Individu merespon lingkungannya didasarkan pada refleks, impuls, persepsi, dan tujuan-tujuan internal; dan didasari juga pada kesempatan-kesempatan yang nyata dan bisa diterima serta reinforcement yang bersifat eksternal.

Motivasi dan belajar merupakan dasar teoritis untuk memahami motivasi dalam pendidikan. Teori ini memberikan dasar bagi pendekatan sistematis pengembangan strategi rancangan motivasional. Motivasi, sebelumnya, ditolak sebagai "jantung" pemahaman akan bagaimana merancang pembelajaran. Awalnya ilmu pembelajaran berkembang dari karya psikologi behavioristik dan cogntive learning yang sebenarnya hanya memberikan pengetahuan akan bagaimana orang belajar, namun tidak memberikan pengetahuan akan mengapa orang belajar. Para ilmuwan pembelajaran yang mulamula (Markle, 1969; Skinner, 1968) menurunkan strategi untuk mengorganisasikan pembelajaran 
untuk meningkatkan penggunaan feedback secara efektif. Strategi ini memerlukan respon aktif dengan kesalahan minimal untuk memberikan suatu konteks bagi penggunaan feedback dan reinforcement.

Performance mengadung arti actual accomplishment. Sementara effort merujuk pada apakah individu tersebut terlibat dalam aksi-aksi yang bertujuan pada pencapaian atau perolehan tugas. Jadi effort merupakan satu indikator langsung dari motivasi. Kita tahu bahwa orang kurang lebih termotivasi oleh persistensi tingkahlakunya. Sebaliknya performance berkaitan dengan pengukuran hasil belajar dan hanya berkaitan secara tidak langsung dengan motivasi, dan dipengaruhi oleh ability (kemampuan) dan opportunity (peluang) dalam konteks learning design and management. Ironisnya, kebanyakan penelitian motivasi dalam pendidikan menggunakan learning atau belajar (diukur dengan angka) sebagai variabel tergantung.

Perbedaan lebih jauh dibuat antara performance dan consequences. Consequences mencakup outcomes intrinsik dan ekstrinsik yang tumbuh dalam diri individu. Semuanya meliputi respon-respon emosional, afeksi, reward sosial dan obyek material. Consequences berkaitan dengan motivasi karena consequences berkaitan dengan evaluasi kognitif (cognitive evaluation) untuk mempengaruhi perubahan-perubahan dalam values atau motives seseorang. Efek consequences terhadap values selanjutnya akan mempengaruhi the degree of effort dalam situasi-situasi serupa di kemudian hari.
Teori Keller berada dalam tradisi teori field atau teori social-leraning, dimana tingkahlaku atau behavior merupakan fungsi dari person $(P)$ dan environment $(E) . \mathrm{B}=\mathrm{f}(\mathrm{P} \& \mathrm{E})$. Teori ini mendeskripsikan pengaruh dari dua faktor $\mathrm{P}$ dan $\mathrm{E}$ terhadap tiga kategori respon: effort, performance, dan consequences. Klasifikasi ini memberikan satu cara yang efektif untuk memadukan penelitian. Faktor $P$ cognitive evaluation, and equity dan faktor E motivational design and management merupakan faktor-faktor yang sangat sedikit diteliti, sementara faktor-faktor lain dari kedua kategori telah banyak diteliti. Dalam teori Keller ini tentang motivasi, performance, dan instructional/school influence secara jelas bertujuan untuk mengidentifikasi kategori-kategori utama dari variabel-variabel tingkahlaku individu (faktor p) dan variabelvariabel rancangan pembelajaran (faktor E) yang berkaitan dengan individual effort and performance.

Berdasarkan teori tentang motivasi tersebut, Keller (1983) mengajukan suatu model rancangan motivasional yang dinamakan Model Attention, Relevance, Confidence, dan Satisfaction (ARCS) yang akan digunakan dalam penelitian ini. Dalam model ini ada empat kategaori dasar yang merupakan variabel-variabel dari motivasi, dan menjadi dasar teori yang mendukungnya. Sebagai model, ARCS terdiri dari separangkat komponen strategi yang mendukung kategori-kategori Attention, Relevance, Confidence, dan Satisfaction. Semua kategori ini memiliki strategi-strategi untuk memperoleh dan mempertahankan attention pebelajar, membangun relevance dalam pembelajaran, confidence dalam diri pebelajar, 
serta menciptakan satisfaction terhadap proses pembelajaran yang ada.

Kategori Attention (interest) terutama mengarah pada munculnya dorongan keingintahuan (curiosity). Dorongan ingin tahu merupakan langkah pertama dalam motivasi untuk mendapatkan dan mempertahankan perhatian pebelajar. Attention juga merupakan langkah pertama dalam teori pemrosesan informasi. Dalam teori ini perhatian terhadap motivasi hanya untuk mendapatkan attention. Sementara dalam pemrosesan informasi, perhatian lebih pada mengarahkan attention tersebut pada apa yang dipelajari.

Attention memiliki strategi-strategi perceptual arousal, inquiry arousal, dan variability. Perceptual arousal bertujuan untuk mendapatkan dan mempertahankan perhatian siswa dalam pembelajaran dengan menggunakan peristiwaperistiwa atau hal-hal yang bersifat baru, memberi kejutan, ketidak-sesuaian, atau peristiwa yang tidak pasti. Strategi inquiry arousal bertujuan merangsang tingkahlaku yang bersifat mencari informasi dengan menyajikan suatu masalah, atau meminta pebelajar menanyakan suatu masalah untuk dipecahkan. Strategi variability bertujuan mempertahankan minat siswa melalui tampilan yang bervariasi dalam berbagai elemen pembelajaran.

Relevance merupakan kategori yang penting sesudah rasa keingintahuan siswa dirangsang (attention). Sesudah terangsang, orang akan bertanya relevansi dari situasi tersebut (outcomes dan conditions) sebelum mereka termotivasi lebih tinggi. Bila siswa bertanya "mengapa saya harus mempelajari pokok bahasan ini?", maka siswa sebenarnya sedang bertanyatanya tentang apa pentingnya pembelajaran itu bagi hidupnya. Secara umum, lebih sulit membangun relevansi dari PKN dan membangun attention. Jika relevansi tidak dibangun melalui faktor-faktor eksternal seperti adanya tuntutan persyaratan tertentu untuk mendapatkan pekerjaan atau adanya persyaratan untuk memasuki perguruan tinggi, maka pengajar harus bisa menemukan cara-cara yang menghubungkan tujuan-tujuan pembelajarannya dengan minat dan motivasi yang utama yang ada dari dalam diri siswa. Relevance memiliki tiga strategi familiarity, goal orientation, dan motive matching. Familiarity nampak melalui penggunaan bahasa yang konkrit, dan contoh serta konsep-konsep yang ada hubungannya dengan pengalaman dan nilai-nilai dari pebelajar itu sendiri. Sedangkan, goal orientation nampak dari pernyataan-pernyataan atau contoh-contoh yang diberikan, yang menonjolkan tujuan dan kegunaan dari pembelajaran, dan apakah strategi ini menyajikan tujuan-tujuan yang akan dicapai, atau meminta pebelajar merumuskannya. Motive matching nampak dari penggunaan strategi pembelajaran sesuai dengan profil motivasi siswa tersebut.

Confidence (expectancy) penting dalam model motivasional. Orang sering menghindar dari pencapaian tujuan yang diinginkan dan yang menarik, karena dia percaya bahwa kemungkinan untuk mencapai tujuan tersebut terlalu kecil. Expektasi positif untuk sukses merupakan prasyarat untuk memotivasi pebelajar. Bila menggunakan risk level (level resiko), levelnya perlu disesuaikan 
berdasarkan tingkat confidence dari pebelajar dan dari jenis tujuan pembelajaran. Orang dewasa, sebagaimana halnya anak-anak yang diharapkan belajar satu ketrampilan baru, perlu diberi kesempatan untuk mendapatkan ketrampilan dan mempraktekkannya dalam kondisi-kondisi dimana resiko psikologisnya rendah; dalam arti mereka butuh kondisi-kondisi dimana mereka tidak harus takut kehilangan muka atau takut saat mencoba mengembangkan ketrampilan tersebut di hadapan orang lain atau teman atau guru. Sementara itu, tingkat resiko atau tantangan tetap diperlukan sekali untuk mendorong pebelajar yang telah menguasai ketrampilan baru tersebut, tujuannya untuk merangsang pebelajar mencapai performansi tertingginya.

Confidence memiliki tiga strategi Expectancy for Succeess, Challenge Setting, dan Attribution Molding. Expectancy for succeess membuat pebelajar sadar akan persyaratan yang diperlukan dalam performansi dan sadar akan kriteria evaluasi yang ada. Sedangkan challenge setting memberikan berbagai tingkatan prestasi yang memungkinkan pebelajar menentukan standar pencapaiannya sendiri dan memberikan kesempatan performansi yang memungkinkan pebelajar mengalami pengalaman sukses. Attribution molding memberikan balikan yang mendukung kemampuan dan usaha siswa sebagai penentu kesuksesan.

Kategori keempat adalah Satisfaction. Pebelajar bisa agak lebih cepat tidak termotivasi bila outcomes dari usahanya tidak sesuai atau konsisten dengan harapannya. Bila sistem penilaian dan evaluasi kelihatannya subyektif dan acak, dan bila orang yang secara intrinsik termotivasi telah terkotak ke dalam sistem external contingency yang diharapkan, maka akan sangat sulit bagi orang tersebut untuk mempertahankan motivasinya terus menerus terhadap pembelajaran. Untuk itu perancang harus memperhatikan keseimbangan antara memelihara dan mempertahankan motivasi intrinsik dan penggunaan reinforcement ekstrinsik yang tidak terhindarkan.

Satisfaction memiliki tiga strategi Natural Consequencies, Positive Consiquences, dan Equity. Natural consequences memberikan kesempatan penggunaan pengetahuan ataupun ketrampilan yang baru diperoleh dalam suatu setting nyata atau setting yang distimulasi. Positive consequences memberikan balikan dan reinforcement yang akan memperkuat tingkahlaku yang diinginkan. Equity merupakan usaha untuk mempertahankan standard dan consequences yang konsisten bagi penyelesaian tugas.

Penerapan Model rancangan motivasional ARCS dalam rancangan pembelajaran harus memperhatikan empat hal penting dalam proses. Keempat peristiwa tersebut Audience Analysis, Motivational Objectives, Strategy Slection, dan Evaluation. Audience Analysis terlihat pada seberapa banyak tekanan diberikan pada kategori tertentu dari motivari. Penggunaan strategi motivasial yang tidak hati-hati sering berakibat pada meningkatnya waktu dan biaya dalam hal pengemabngan dan implementasinya. Karena itu perancang perlu tahu betul jenis problem motivasi apa yang betul-betul nyata untuk ditangani. Motivational Objectives merujuk pada tingkahlaku 
siswa yang ingin diamati oleh pengajar berkaitan dengan faktor motivasional. Tujuannya bisa tujuan motivasional kognitif, afektif, atau psikomotor. Strategy Selection mengharuskan pengajar ataupun perancang untuk memilih atau menciptakan bahasa dan kegiatan yang membantu tercapainya motivational objectives. Keller memberikan penuntun yang bermanfaat dalam proses seleksi strategi, dimana strategi motivasi sebaiknya: tidak menghabiskan banyak waktu; tidak menyimpang dari tujuan belajar; berada dalam batas-batas waktu dan biaya fase pengembangan dan implementasi pembelajaran; bisa diterima oleh audience; dan selaras dengan sistem penyampaian, termasuk gaya pribadi pengajar. Evalution bukan diukur terutama pada prestasi sebagaimana biasanya, tetapi diukur secara khusus dari pencapaian tujuan-tujuan motivasional.

Model rancangan motivasional ARCS dapat dilakukan pada semua bidang studi. Penelitian ini memilih bidang studi PKN sebagai sarana uji coba produk model rancangan motivasional, mengingat bidang studi PKN sedang mendapat perhatian. Berbagai temuan penelitian menyatakan bahwa prestasi siswa pada bidang PKN masih rendah. Rendahnya kualitas siswa dalam bidang studi ini diduga disebabkan karena rancangan pembelajaran yang disusun guru, belum mempertimbangkan unsur motivasi. Oleh karena itu penelitian yang berkaitan dengan strategi motivasional sangat urgen untuk dilakukan. Penelitian ini akan mengadaptasi model rancangan motivasional ARCS yang dikembangkan Keller (1983, 1987) untuk pembelajaran PKN di Sekolah Menengah Petama ( Lihat Diagram.1)

Model Pembelajaran ARCS. Model pembelajaran ARIAS merupakan modifikasi dari model ARCS. Model ARCS (Attention, Relevance, Confidence, Satisfaction), dikembangkan oleh Keller dan Kopp (1987: 2-9) sebagai jawaban pertanyaan bagaimana merancang pembelajaran yang dapat mempengaruhi motivasi berprestasi dan hasil belajar. Model pembelajaran ini dikembangkan berdasarkan teori nilai harapan

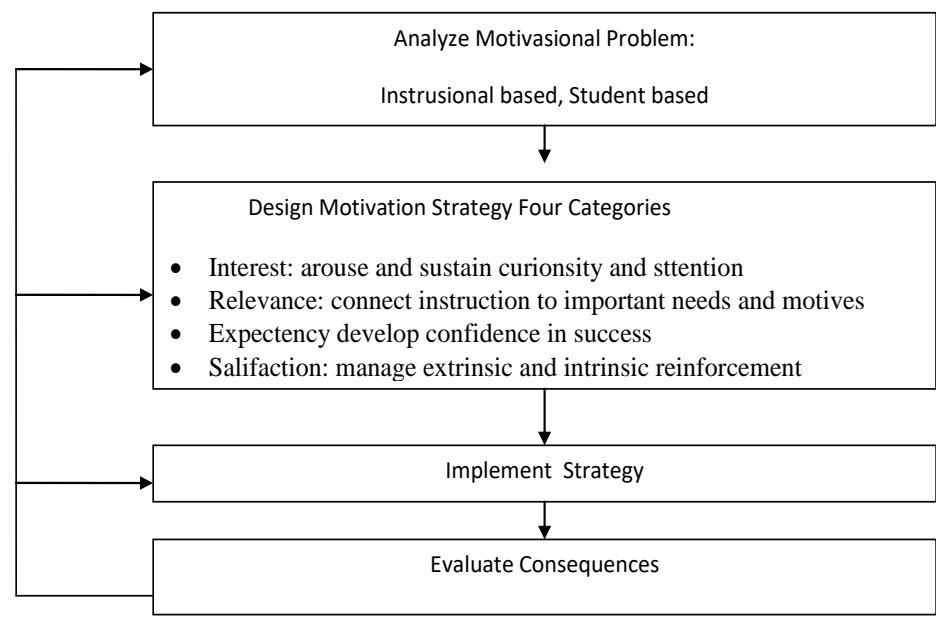

Gambar 1 Model Merancang Pembelajaran Motivasional (Keller, 1983 : 396) 
(expectancy value theory) yang mengandung dua komponen yaitu nilai (value) dari tujuan yang akan dicapai dan harapan (expectancy) agar berhasil mencapai tujuan itu. Dari dua komponen tersebut oleh Keller dikembangkan menjadi empat komponen. Keempat komponen model pembelajaran itu adalah attention, relevance, confidence dan satisfaction dengan akronim ARCS (Keller dan Kopp, 1987: 289-319).

Model pembelajaran ini menarik karena dikembangkan atas dasar teori-teori belajar dan pengalaman nyata para instruktur (Bohlin, 1987: 11-14). Namun demikian, pada model pembelajaran ini tidak ada evaluasi (assessment), padahal evaluasi merupakan komponen yang tidak dapat dipisahkan dalam kegiatan pembelajaran. Evaluasi yang dilaksanakan tidak hanya pada akhir kegiatan pembelajaran tetapi perlu dilaksanakan selama proses kegiatan berlangsung. Evaluasi dilaksanakan untuk mengetahui sampai sejauh mana kemajuan yang dicapai atau hasil belajar yang diperoleh siswa (DeCecco, 1968: 610). Evaluasi yang dilaksanakan selama proses pembelajaran menurut Saunders et al. seperti yang dikutip Beard dan Senior (1980: 72) dapat mempengaruhi hasil belajar siswa. Mengingat pentingnya evaluasi, maka model pembelajaran ini dimodifikasi dengan menambahkan komponen evaluasi pada model pembelajaran tersebut.

Dengan modifikasi tersebut, model pembelajaran yang digunakan mengandung lima komponen yaitu: attention (minat/perhatian); relevance (relevansi); confidence (percaya/yakin); satisfaction (kepuasan/bangga), dan assessment (evaluasi). Modifikasi juga dilakukan dengan penggantian nama confidence menjadi assurance, dan attention menjadi interest. Penggantian nama confidence (percaya diri) menjadi assurance, karena kata assurance sinonim dengan kata selfconfidence (Morris, 1981: 80). Dalam kegiatan pembelajaran guru tidak hanya percaya bahwa siswa akan mampu dan berhasil, melainkan juga sangat penting menanamkan rasa percaya diri siswa bahwa mereka merasa mampu dan dapat berhasil. Demikian juga penggantian kata attention menjadi interest, karena pada kata interest (minat) sudah terkandung pengertian attention (perhatian). Dengan kata interest tidak hanya sekedar menarik minat/perhatian siswa pada awal kegiatan melainkan tetap memelihara minat/perhatian tersebut selama kegiatan pembelajaran berlangsung. Untuk memperoleh akronim yang lebih baik dan lebih bermakna maka urutannya pun dimodifikasi menjadi assurance, relevance, interest, assessment dan satisfaction. Makna dari modifikasi ini adalah usaha pertama dalam kegiatan pembelajaran untuk menanamkan rasa yakin/percaya pada siswa. Kegiatan pembelajaran ada relevansinya dengan kehidupan siswa, berusaha menarik dan memelihara minat/perhatian siswa. Kemudian diadakan evaluasi dan menumbuhkan rasa bangga pada siswa dengan memberikan penguatan (reinforcement). Dengan mengambil huruf awal dari masing-masing komponen menghasilkan kata ARCS sebagai akronim. Oleh karena itu, model pembelajaran yang sudah dimodifikasi ini disebut model pembelajaran ARCS. 


\section{Komponen Model Pembelajaran ARCS.}

Komponen pertama model pembelajaran ARCS adalah assurance (percaya diri), yaitu berhubungan dengan sikap percaya, yakin akan berhasil atau yang berhubungan dengan harapan untuk berhasil (Keller, 1987: 2-9). Menurut Bandura seperti dikutip oleh Gagne dan Driscoll (1988: 70) seseorang yang memiliki sikap percaya diri tinggi cenderung akan berhasil bagaimana pun kemampuan yang ia miliki. Sikap di mana seseorang merasa yakin, percaya dapat berhasil mencapai sesuatu akan mempengaruhi mereka bertingkah laku untuk mencapai keberhasilan tersebut. Sikap ini mempengaruhi kinerja aktual seseorang, sehingga perbedaan dalam sikap ini menimbulkan perbedaan dalam kinerja. Sikap percaya, yakin atau harapan akan berhasil mendorong individu bertingkah laku untuk mencapai suatu keberhasilan (Petri, 1986: 218). Siswa yang memiliki sikap percaya diri memiliki penilaian positif tentang dirinya cenderung menampilkan prestasi yang baik secara terus menerus (Prayitno, 1989: 42). Sikap percaya diri, yakin akan berhasil ini perlu ditanamkan kepada siswa untuk mendorong mereka agar berusaha dengan maksimal guna mencapai keberhasilan yang optimal. Dengan sikap yakin, penuh percaya diri dan merasa mampu dapat melakukan sesuatu dengan berhasil, siswa terdorong untuk melakukan sesuatu kegiatan dengan sebaik-baiknya sehingga dapat mencapai hasil yang lebih baik dari sebelumnya atau dapat melebihi orang lain.

Komponen kedua model pembelajaran ARCS, relevance, yaitu berhubungan dengan kehidupan siswa baik berupa pengalaman sekarang atau yang telah dimiliki maupun yang berhubungan dengan kebutuhan karir sekarang atau yang akan datang (Keller, 1987: 2-9). Siswa merasa kegiatan pembelajaran yang mereka ikuti memiliki nilai, bermanfaat dan berguna bagi kehidupan mereka. Siswa akan terdorong mempelajari sesuatu kalau apa yang akan dipelajari ada relevansinya dengan kehidupan mereka, dan memiliki tujuan yang jelas. Sesuatu yang memiliki arah tujuan, dan sasaran yang jelas serta ada manfaat dan relevan dengan kehidupan akan mendorong individu untuk mencapai tujuan tersebut. Dengan tujuan yang jelas mereka akan mengetahui kemampuan apa yang akan dimiliki dan pengalaman apa yang akan didapat. Mereka juga akan mengetahui kesenjangan antara kemampuan yang telah dimiliki dengan kemampuan baru itu sehingga kesenjangan tadi dapat dikurangi atau bahkan dihilangkan sama sekali (Gagne dan Driscoll, 1988: 140).

Komponen ketiga model pembelajaran ARCS, interest, adalah yang berhubungan dengan minat/perhatian siswa. Menurut Woodruff seperti dikutip oleh Callahan (1966: 23) bahwa sesungguhnya belajar tidak terjadi tanpa ada minat/perhatian. Keller seperti dikutip Reigeluth (1987: 383-430) menyatakan bahwa dalam kegiatan pembelajaran minat/perhatian tidak hanya harus dibangkitkan melainkan juga harus dipelihara selama kegiatan pembelajaran berlangsung. Oleh karena itu, guru harus memperhatikan berbagai bentuk dan memfokuskan pada minat/perhatian dalam kegiatan pembelajaran. Herndon (1987:1114) menunjukkan bahwa adanya minat/perhatian siswa terhadap tugas yang diberikan dapat mendorong siswa melanjutkan tugasnya. Siswa 
akan kembali mengerjakan sesuatu yang menarik sesuai dengan minat/perhatian mereka. Membangkitkan dan memelihara minat/perhatian merupakan usaha menumbuhkan keingintahuan siswa yang diperlukan dalam kegiatan pembelajaran. Minat atau perhatian merupakan alat yang sangat berguna dalam usaha mempengaruhi hasil belajar siswa.

Komponen keempat model pembelajaran ARCS adalah assessment, yaitu yang berhubungan dengan evaluasi terhadap siswa. Evaluasi merupakan suatu bagian pokok dalam pembelajaran yang memberikan keuntungan bagi guru dan murid (Lefrancois, 1982: 336). Bagi guru menurut Deale seperti dikutip Lefrancois (1982: 336) evaluasi merupakan alat untuk mengetahui apakah yang telah diajarkan sudah dipahami oleh siswa; untuk memonitor kemajuan siswa sebagai individu maupun sebagai kelompok; untuk merekam apa yang telah siswa capai, dan untuk membantu siswa dalam belajar. Bagi siswa, evaluasi merupakan umpan balik tentang kelebihan dan kelemahan yang dimiliki, dapat mendorong belajar lebih baik dan meningkatkan motivasi berprestasi (Hopkins dan Antes, 1990:31). Evaluasi terhadap siswa dilakukan untuk mengetahui sampai sejauh mana kemajuan yang telah mereka capai. Apakah siswa telah memiliki kemampuan seperti yang dinyatakan dalam tujuan pembelajaran (Gagne dan Briggs, 1979:157).

Evaluasi tidak hanya dilakukan oleh guru tetapi juga oleh siswa untuk mengevaluasi diri mereka sendiri (self assessment) atau evaluasi diri. Evaluasi diri dilakukan oleh siswa terhadap diri mereka sendiri, maupun terhadap teman mereka.
Hal ini akan mendorong siswa untuk berusaha lebih baik lagi dari sebelumnya agar mencapai hasil yang maksimal. Mereka akan merasa malu kalau kelemahan dan kekurangan yang dimiliki diketahui oleh teman mereka sendiri.

Evaluasi terhadap diri sendiri merupakan evaluasi yang mendukung proses belajar mengajar serta membantu siswa meningkatkan keberhasilannya (Soekamto, 1994). Hal ini sejalan dengan yang dikemukakan Martin dan Briggs seperti dikutip Bohlin (1987: 11-14) bahwa evaluasi diri secara luas sangat membantu dalam pengembangan belajar atas inisiatif sendiri. Dengan demikian, evaluasi diri dapat mendorong siswa untuk meningkatkan apa yang ingin mereka capai. Ini juga sesuai dengan apa yang dikemukakan Morton dan Macbeth seperti dikutip Beard dan Senior (1980: 76) bahwa evaluasi diri dapat mempengaruhi hasil belajar siswa. Oleh karena itu, untuk mempengaruhi hasil belajar siswa evaluasi perlu dilaksanakan dalam kegiatan pembelajaran.

Komponen kelima model pembelajaran ARCS adalah satisfaction yaitu yang berhubungan dengan rasa bangga, puas atas hasil yang dicapai. Dalam teori belajar satisfaction adalah reinforcement (penguatan). Siswa yang telah berhasil mengerjakan atau mencapai sesuatu merasa bangga/puas atas keberhasilan tersebut. Keberhasilan dan kebanggaan itu menjadi penguat bagi siswa tersebut untuk mencapai keberhasilan berikutnya (Gagne dan Driscoll, 1988: 70).

Reinforcement atau penguatan yang dapat memberikan rasa bangga dan puas pada siswa adalah penting dan perlu dalam kegiatan pembelajaran (Hilgard dan Bower, 1975:561). 


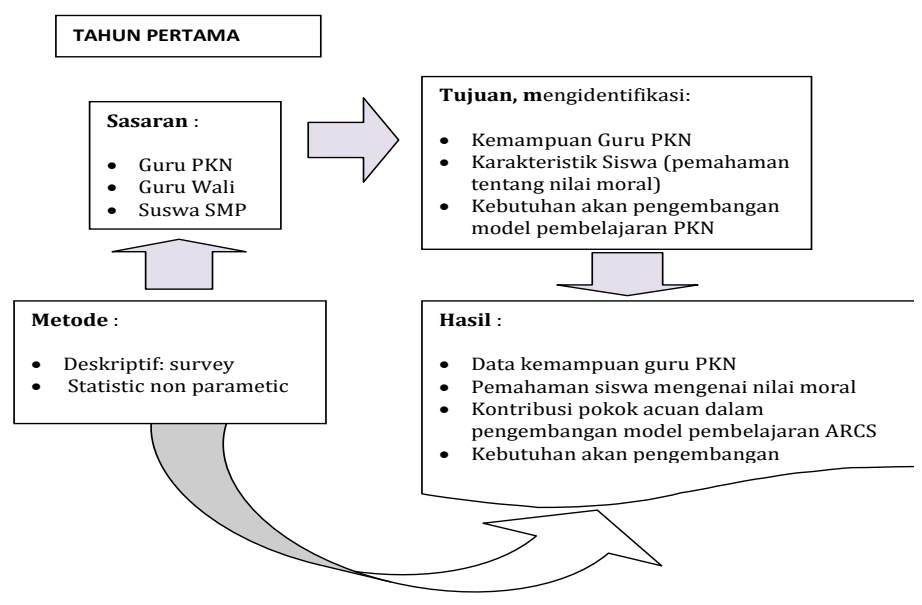

Gambar 2. Rancangan Penelitian

Menurut Keller berdasarkan teori kebanggaan, rasa puas dapat timbul dari dalam diri individu sendiri yang disebut kebanggaan intrinsik di mana individu merasa puas dan bangga telah berhasil mengerjakan, mencapai atau mendapat sesuatu. Kebanggaan dan rasa puas ini juga dapat timbul karena pengaruh dari luar individu, yaitu dari orang lain atau lingkungan yang disebut kebanggaan ekstrinsik (Keller dan Kopp, 1987: 2-9).

Seseorang merasa bangga dan puas karena apa yang dikerjakan dan dihasilkan mendapat penghargaan baik bersifat verbal maupun nonverbal dari orang lain atau lingkungan. Memberikan penghargaan (reward) menurut Thorndike seperti

dikutip oleh Gagne dan Briggs (1979) merupakan suatu penguatan (reinforcement) dalam kegiatan pembelajaran. Dengan demikian, memberikan penghargaan merupakan salah satu cara yang dapat digunakan untuk mempengaruhi hasil belajar siswa (Hilgard dan Bower, 1975: 561). Untuk itu, rasa bangga dan puas perlu ditanamkan dan dijaga dalam diri siswa.

\section{Penggunaan Model Pembelajaran ARCS.}

Penggunaan model pembelajaran ARCS perlu dilakukan sejak awal, sebelum guru melakukan kegiatan pembelajaran di kelas. Model pembelajaran ini digunakan sejak guru atau perancang merancang kegiatan pembelajaran dalam bentuk satuan pelajaran misalnya. Satuan pelajaran sebagai pegangan (pedoman) guru kelas dan satuan pelajaran sebagai bahan/materi bagi siswa. Satuan pelajaran sebagai pegangan bagi guru disusun sedemikian rupa, sehingga satuan pelajaran tersebut sudah mengandung komponen-komponen ARCS. Artinya, dalam satuan pelajaran itu sudah

tergambarkan usaha/kegiatan yang akan dilakukan untuk menanamkan rasa percaya diri pada siswa, mengadakan kegiatan yang relevan, membangkitkan minat/perhatian siswa, melakukan evaluasi dan menumbuhkan rasa dihargai/bangga pada siswa. Guru atau pengembang sudah merancang urutan semua kegiatan yang akan dilakukan, strategi atau metode pembelajaran yang akan digunakan, media pembelajaran apa yang 
akan dipakai, perlengkapan apa yang dibutuhkan, dan bagaimana cara penilaian akan dilaksanakan. Meskipun demikian pelaksanaan kegiatan pembelajaran disesuaikan dengan situasi, kondisi dan lingkungan siswa. Demikian juga halnya dengan satuan pelajaran sebagai bahan/materi untuk siswa. Bahan/materi tersebut harus disusun berdasarkan model pembelajaran ARCS. Bahasa, kosa kata, kalimat, gambar atau ilustrasi, pada bahan/materi dapat menumbuhkan rasa percaya diri pada siswa, bahwa mereka mampu, dan apa yang dipelajari ada relevansi dengan kehidupan mereka. Bentuk, susunan dan isi bahan/materi dapat membangkitkan minat/perhatian siswa, memberi kesempatan kepada siswa untuk mengadakan evaluasi diri dan siswa merasa dihargai yang dapat menimbulkan rasa bangga pada mereka. Guru dan/atau pengembang agar menggunakan bahasa yang mudah dipahami dan dimengerti, kata-kata yang jelas dan kalimat yang sederhana tidak berbelit-belit sehingga maksudnya dapat dengan mudah ditangkap dan dicerna siswa. Bahan/materi agar dilengkapi dengan gambar yang jelas dan menarik dalam jumlah yang cukup. Gambar dapat menimbulkan berbagai macam khayalan/fantasi dan dapat membantu siswa lebih mudah memahami bahan/materi yang sedang dipelajari.

Tujuan penelitian (1) mendeskripsikan prestasi belajar siswa dalam bidang studi PKN pada enam kecamatan di Kabupaten Minahasa; (2) mendeskripsikan motivasi belajar siswa SMP pada enam kecamatan di Kabupaten Minahasa; (3) Mendeskripsikan strategi pengelolaan motivasional yang dilakukan guru-guru Bidang Studi PKN pada enam kecamatan di Kabupaten Minahasa; (4)
Mengembangkan model rancangan motivasional pada pembelajaran PKN Di SMP.

\section{METODE PENELITIAN}

Fokus penelitian ini terdiri dari dua jenis, yaitu: (1) mendeskripsikan motivasi belajar siswa dan strategi motivasional yang dilakukan guru dan mengembangkan model rancangan motivasional untuk rancangan pembelajaran PKN Di SMP.

Rancangan penelitian untuk mendeskripsikan motivasi belajar siswa dan strategi motivasional yang dilakukan guru menggunakan teknik survey. Sedangkan untuk mengembangkan model rancangan motivasional menggunakan teknik pengembangan.

Rancangan penelitian pengembangan dipakai untuk mengembangkan model rancangan motivasional. Langkah-langkah pengembangan model tersebut sebagai berikut: (1) mengembangkan model rancangan motivasional berdasarkan temuan penelitian untuk rancangan pembelajaran PKN di SMP, (2) uji ahli, melibatkan ahli psikologi belajar, teknologi pembelajaran, ahli pendidikan PKN. (3) revisi model rancangan motivasional tersebut berdasarkan saran ahli, (3) uji coba perorangan (guru), (4) uji coba kelompok kecil (guru), (5) uji coba lapangan (guru dan siswa), dan (6) pengembangan model rancangan motivasional dalam rancangan pembelajaran (prototipe akhir).

Adapun rancangan penelitian yang digunakan pada penelitian tahun pertama ini mengikuti alur penelitian berikut ini. 


\section{Instrumen dan Validasi Instrumen.}

Instrumen yang digunakan untuk memperoleh data motivasi belajar siswa dan strategi motivasional yang dilakukan guru akan disusun oleh tim peneliti. Sebelum instrumen tersebut digunakan terlebih dahulu dilakukan uji coba intrumen untuk mengetahui tingkat validitas dan reliabilitas instrumen. Instrumen untuk memvalidasi model yang telah dikembangkan, disusun sendiri oleh tim peneliti.

\section{Subyek Penelitian}

Subjek penelitian untuk memperoleh deskripsi motivasi belajar dan strategi motivasional sekolah SMP di enam kecamatan di Kabupaten Minahasa yang mewakili kecamatan besar, sedang, dan kecil yaitu siswa dan guru SMP. Subyek penelitian untuk mengembangkan model pembelajaran adalah ahli psikologi belajar ( 2 orang), ahli teknologi pembelajaran (2 orang), dan ahli pendidikan Ilmu-ilmu sosial/PKN (2 orang). Sedangkan subyek penelitian untuk uji coba adalah guru dan siswa.

\section{Analisis Data}

Analisis data yang dipakai untuk memperoleh data motivasi belajar siswa, strategi motivasional yang dilakukan guru menggunakan analisis deskriptif. Sedangkan untuk mengembangkan model adalah analisis deskriptif berbentuk prosentase kesepakatan di antara para ahli dan subyek penelitian.

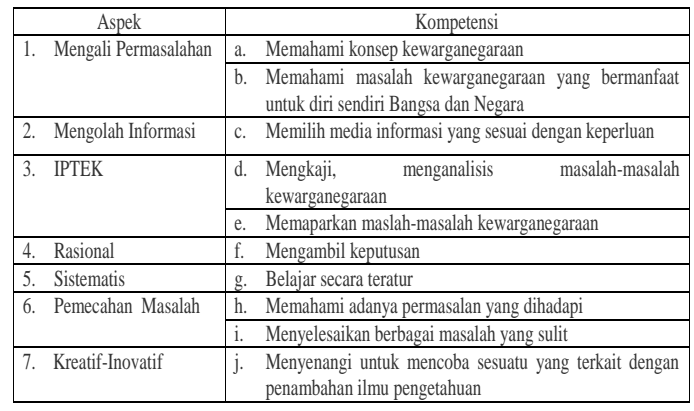

\section{HASIL DAN PEMBAHASAN}

Penelitian ini melibatkan 1.179 tenaga pengajar pada tingkat SMP (PNS 729 \& Honorer 450)dan dengan jumlah siswa 13.492 pada 6 Kec di Kab Minahasa. Di Kec Minahasa/Tondano Utara: 1 SMP Neg dan 1 SMP Swasta; Minahasa/Tondano Timur: 2 SMP Neg \& 1 SMP swasta; Minahasa/Tondano Barat: 1 SMP Swasta; Langoan 2 SMP Neg dan 1 SMP Swasta; Remboken: 1 SMP Neg dan 1 SMP Swasta; Kawangkoan: 2 SMP Neg dan 2 SMP Swasta. Sedangkan jumlah siswa 13.492 yang terdiri dari laki-laki $4.125(43,23 \%)$ dan Perempuan 5.417 (56,77\%).

Melibatkan 1.179 guru, 527 pria dan 652 wanita. karakteristik responden yaitu: (1) wanita $(54,73 \%)$, (2) usia 36 - 40 tahun $(320,95 \%)$, (3) tingkat pendidikan sarjana $(90,54 \%)$, dan (4) pengalaman kerja 11-15 tahun (31\%). Sebaran data

ini berdasarkan pada data guru pengasuh mata pelajaran PKN.

\section{Data Analisis Kebutuhan (Need Assesment) Data} analisis membuktikan bahwa: (1) 97,28 \% responden sangat setuju, (2) 95,27\% responden menyatakan sangat dibutuhkan mata pelajaran PKn sebagai sarana pembentukkan karakter bangsa, (3) 97,28 \% responden menyatakan sangat setuju akan 
adanya pengembangan pembelajaran yang dapat merangsang ketertarikan siswa, (4) 95,27\% sangat setuju akan tersedianya bahan ajar dengan model pembelajaran yang inovatif, serta (5) isi model pembelajaran yang menyangkut: a) tujuan pembelajaran, b) organisasi materi, c) alokasi waktu, d) strategi pembelajaran, e) alat evaluasi, f) sumber belajar, g) literatur.

Sebagaimana hasil penelitian yang dipaparkan dalam kegiatan seminar pemantauan, masyarakat memandang bahwa kompetensi lulusan SMP harus meliputi empat dimensi kompetensi, yakni: dimensi akademik, personal, sosial dan vokasional.

\section{a. Kompetensi Akademik}

\section{b.Kompetensi Kualitas Personal}

Kemampuan peserta didik yang berkenan dengan pemahaman akan keberadaan diri sendiri dan menerima akan tugas dan kewajibannya secara pribadi sebagai seorang insan.

\begin{tabular}{|c|c|}
\hline Aspek & Kemampuan \\
\hline 1. Imtaq & $\begin{array}{l}\text { a. Melaksanakan kewajiban berdasarkan norma- } \\
\text { norma yang berlaku dalam masyarakat }\end{array}$ \\
\hline $\begin{array}{ll}2 . & \text { Tanggung } \\
\text { Jawab }\end{array}$ & $\begin{array}{l}\text { b. Berani mengakui kekeliruan atau kesalahan yang } \\
\text { diperbuatnya }\end{array}$ \\
\hline 3. Jujur & $\begin{array}{l}\text { c. Bersikap jujur terhadap diri sendiri, masyarakat } \\
\text { sekitarnya }\end{array}$ \\
\hline Mandiri & d. $\quad$ Mampu bersikap mandiri \\
\hline $\begin{array}{l}\text { 5. Potensi } \\
\text { Diri }\end{array}$ & $\begin{array}{l}\text { e. Menyadari sifat yang kurang baik yang } \\
\text { dimilikinva. }\end{array}$ \\
\hline
\end{tabular}

Tabel 1. Data Aktifitas Siswa yang Relevan dengan Pembelajaran

\begin{tabular}{|c|c|c|}
\hline & Aspek & Kemampuan \\
\hline \multirow{6}{*}{\multicolumn{2}{|c|}{\begin{tabular}{ll}
\multicolumn{1}{c}{ Aspek } \\
1. & $\begin{array}{l}\text { Potensi } \\
\text { Lingkungan }\end{array}$
\end{tabular}}} & $\begin{array}{l}\text { a. Memahami keanekaragaman jenis pekerjaan yang ada di } \\
\text { lingkungannya }\end{array}$ \\
\hline & & $\begin{array}{l}\text { b. Mengetahui jenis pekerjaan yang paling sesuai dengan } \\
\text { kemampuan serta menguntungkan bagi dirinya }\end{array}$ \\
\hline & & $\begin{array}{l}\text { c. Mengetahui dan dapat menghitung modal yang dibutuhkan } \\
\text { dalam suatu pekerjaan }\end{array}$ \\
\hline & & $\begin{array}{l}\text { d. Memahami keadaan alam dan potensi lingkungan yang } \\
\text { bisa dijadikan objek pekerjaan }\end{array}$ \\
\hline & & $\begin{array}{l}\text { e. Mengenal lingkungan budaya, termasuk adat istiadat dan } \\
\text { tradisi yang berlaku di daerahnya }\end{array}$ \\
\hline & & $\begin{array}{l}\text { f. Mempunyai kepedulian terhadap kebersihan lingkungan } \\
\text { dan keamanan kerja }\end{array}$ \\
\hline & \multirow[t]{6}{*}{$\begin{array}{l}\text { Kesiapan } \\
\text { keterampilan }\end{array}$} & $\begin{array}{l}\text { g. Menguasai dasar-dasar keterampilan yang dibutuhkan } \\
\text { untuk melakukan suatu jenis pekerjaan }\end{array}$ \\
\hline & & $\begin{array}{l}\text { h. Memiliki semangat dan etos kerja yang tinggi dan bekerja } \\
\text { tidak mengharapkan pujian }\end{array}$ \\
\hline & & $\begin{array}{l}\text { i. Memiliki motivasi yang tinggi dan kreativitas untuk } \\
\text { menciptakan suatu pekerjaan }\end{array}$ \\
\hline & & $\begin{array}{l}\text { j. Memiliki kesadaran akan pentingnya melakukan suatu } \\
\text { pekerjaan }\end{array}$ \\
\hline & & k. Memiliki ketekunan dalam belajar dan bekerja \\
\hline & & $\begin{array}{l}\text { Mampu bekerja keras untuk mencapai prestasi yang lebih } \\
\text { baik }\end{array}$ \\
\hline
\end{tabular}

\section{C.Kompetensi Psikomotorik.}

Kemampuan perserta didik berkenaan dengan kesiapan dan keterampilan spesifik yang dimiki untuk melakukan suatu pekerjaan/bekerja di suatu bidang pekerjaan. Berdasarkan Tabel 1. di atas, dapat dilihat bahwa aktivitas siswa yang relevan dengan kegiatan pembelajaran PKN ratarata 32,09\% dimana menunjukkan perlu adanya upayakan untuk meningkatkan motivasi dan ketertarikan siswa pada mata pelajara PKn dengan mengembangkan model pembelajaran yang inovatif melalui model pembelajaran motivasional yang dikenal dengan model ARCS.

Selanjutnya data aktivitas siswa yang kurang relevan dengan pembelajaran terlihat pada Table 2.

Table 2. Data Aktivitas Siswa yang kurang relevan dengan pembelajaran

\begin{tabular}{c|l|c}
\hline No & \multicolumn{1}{|c|}{ Indikator } & Ketercapaian \\
\hline 1 & Tidak memperhatikan penjelasan guru & $63,51 \%$ \\
\hline 2 & Mengobrol dengan teman & $68,81 \%$ \\
\hline 3 & Mengerjakan tugas lain & $77,02 \%$ \\
\hline & Rata - rata & $69,78 \%$ \\
\hline
\end{tabular}

Berdasarkan Tabel 2 di atas dapat dilihat bahwa aktivitas siswa yang kurang relevan dengan kegiatan pembelajaran rata-rata 69,78 dalam arti

\begin{tabular}{|c|l|r}
\hline No & \multicolumn{1}{|c|}{ Indikator } & Ketercapaia \\
\hline 1 & $\begin{array}{l}\text { Keberanian siswa dalam bertanya dan mengemukakan } \\
\text { pendapat }\end{array}$ & $33,11 \%$ \\
\hline 2 & $\begin{array}{l}\text { Motivasi dan kegairahan dalam mengikuti pembelajaran } \\
\text { (meyelesaikan tugas mandiri atau tugas kelompok })\end{array}$ & $27,70 \%$ \\
\hline 3 & Interaksi siswa dalam mengikuti diskusi kelompok & $33,11 \%$ \\
\hline 4 & $\begin{array}{l}\text { Hubungan siswa dengan guru selama kegiatan } \\
\text { pembelajaran }\end{array}$ & $36,49 \%$ \\
\hline 5 & $\begin{array}{l}\text { Hubungan siswa dengan siswa lain selama pembelajaran } \\
\text { (Dalam kerja kelompok) }\end{array}$ & $34,46 \%$ \\
\hline 6 & $\begin{array}{l}\text { Partisipasi siswa dalam pembelajaran (memperhatikan), } \\
\text { ikut melakukan kegiatan kelompok, selalu mengikuti } \\
\text { petunjuk guru). }\end{array}$ & $27,70 \%$ \\
\hline & Rata=rata \\
\hline
\end{tabular}


cukup tinggi ketidak seriusan dan tingkat kejenuhan siswa dalam mengikuti pembelajaran PKN yang selama ini di laksanakan jika menggunakan metode pembelajaran yang konvensional. Berdasarkan data yang diperoleh maka dapat dianalisis bahwa pada pembelajaran PKN yang selama ini diajarkan kurang menarik bagi siswa sehingga terdapat ketidak-seriusan siswa dalam mengikuti pelajaran PKN yang berdampak pada merosotnya nilai atau prestasi belajar siswa pada bidang studi PKN.

Penelitian yang dilakukan pada pada 148 guru di SMP Negeri dan swasta di Minahasa menunjukkan bawa 90,54 \% guru berijasah sarjana dengan pengalaman kerja dengan populasi yang tertinggi pada sebaran pengalaman kerja 11-15 tahun. Berdasarkan data yang terlihat pada tabel 4 menunjukkan bahwa kebutuhan akan model pembelajaran yang inovatif variatif yang dapat merangsang ketertarikan siswa dalam pembelajaran PKn serta memudahkan guru dalam pencapaian tujuan yang ditetapkan, didapati ratarata $97,77 \%$ menyatakan akan kebutuhan akan hal tersebut. Sedangkan tentang karakteristik siswa yang mengikuti pelajaran PKn yang berhubungan dengan aktifitas siswa yang relevan dengan mata pelajaran PKn, didapati rata-rata 32,09\% melakukan kegitan yang relevan dengan kegiatan pembelajaran.Angka ini menunjukkan bahwa siswa lebih banyak melakukan hal-hal yang tidak relevan.Untuk kegitan siswa yang melakukan yang tidak relevan dengan kegiatan pembelajaran didapati siswa dengan prosentase rata-rata $69,78 \%$. Angka ini menunjukkan tentang tingginya jumlah siswa yang tidak serius bahkan tidak tertarik dengan pelaksanaan proses pembelajaran.

\section{KESIMPULAN DAN SARAN}

\section{Kesimpulan}

Hasil analisis kebutuhan bahwa: 1) 97,28 \% sangat setuju untuk usaha mengatasi kecenderungan akan gejala menurunnya prestasi belajar siswa SMP di Kabupaten Minahasa perlu dikembangkan model pembelajaran yang inovatif.dengan model ARCS; 2) 95,27 \% Responden menyatakan sangat setuju dengan kedudukan mata pelajaran PKN sebagai pembentukan karakter bangsa; 3) 97,28 \% sangat setuju dengan pengembangan model ARCS dalam pembelajaran PKN; 4) 95,27 sangat diperlukan bahan ajar untuk mempermudah guru dalam proses belajar mengajar. 5) sangat setuju untuk dibuat model rencana pelaksana pembelajaran dengan sistematika sebagai berikut: Tujuan Pembelajaran; Organisasi Materi; Strategi Pembelajaran (model pembelajaran sesuai materi); Alokasi Waktu; Sumber belajar; Alat Evaluasi; Literature.

\section{Saran}

Berkaitan dengan pemanfaatan hasil penelitian ini, maka disarankan sebagai berikut :

1. Dalam kegiatan pembelajaran di kelas, sebaiknya guru bidang studi PKn dapat mengunakan pedoman kajian analitik bahan pembelajaran PKn untuk Siswa SMP agar dapat memudahkan dalam aktifitas pembelajarannya. Saat mengunakan produk hasil penelitian ini sebagai salah satu sumber belajar,sebaiknya siswa memahami tujuan pembelajaran yang ingin dicapai. 
2. Dalam pembelajaran PKn, khususnya produk yang dikembangkan, sebaiknya guru dapat memperkaya penyajian materi di kelas dengan mengunakan media pembelajaran yang sesuai dengan materi yang diajarkan agar dapat memudahkan dalam proses belajar-mengajar dikelas sehingga dapat memberikan daya tarik dalam pembelajaran PKn dengan model ARCS.

3. Berkaitan dengan aspek desiminasi hasil penelitian, maka produk hasil penelitian ini yang berupa bahan pembelajaran PKn dengan model ARCS melalui yang diajarkan pada siswa, disarankan agar dapat disebarluaskan pengunaannya dalam lingkungan yang lebih luas terutama pada Sekolah Menengah Pertama yang ada di 6 kecamatan di Minahasa.

\section{DAFTAR PUSATAKA}

Ardhana, W. 1994. Siswa Memerlukan Tantangan, Bukan Keberhasilan yang Diraih dengan Mudah. Makalah Disampaikan dalam Seminar Sehari tentang Peningkatan Sumber Daya Manusia dalam Menyongsong Kurikulum 1994 di Universitas 17 Agustus 1945 Surabaya.

Bloom, B.S. 1976. Human Characteristic and School Learning. New York:McGraw-Hill.

Colley, W.W. \& Lohnes, P.R. 1976. Evaluation Research of Education. New York: Halsted

Elliot, S.N., Kratochwill, T.R., Littlefield, J., \& Travers, J.F. 1996. Educational Psychology ( $2^{\text {nd }}$ Ed.). Madison: Brown \& Benchmark

Ford, M. 1992. Motivating Humans. Newbury Park, CA: Sage.

Gagne, R.M. 1977. The Condition of Learning (3rd ed). New York: Holt Rinehart \& Winston.
Keller, J.M. 1978. Motivational Need Game. National Society for Performance and Instruction Jurnal, 17(6), 3-4, 21.

Keller, J.M. 1979. Motivational and Instruction Design. Journal of Instructional Development 2(4), 26-34.

Keller, J.M., Goldman, J.A., \& Sutterer, J.R. 1978. Locus of Control in Relation to Academic Attitudes and Performance in a Personalized System of Instruction Course. Journal of Educational Psychology, 79, 414421.

Keller, J.M. 1983. Motivational Design of Instruction. Dalam Reigeluth, C.M. (Ed.) 1983. Instructional-Design Theories and Models: An Overview of their Current Status. Hillsdale, New Jersey: Lawrence Erlbaum Associates.

Keller, J.M. 1987. Application of the ARCS Model of Mativational Design. Dalam Reigeluth, C.M. (Ed.) 1987. Instructional Theories In Action: Lessons Illustrating Selected Theories and Models. Hillsdale, New Jersey: Lawrence Erlbaum Associates.

Keller, J.M. 1996. Motivation in instructional design. Dalam T. Plomp \& D.P. Ely (Ed). International Encyclopedia of Educational Technology (2 ${ }^{\text {nd }}$ Ed). New York: Pergamon.

Reigeluth, C.M. 1979. In search of a Better Way to Organize Instruction. Journal of Instructioanl Development, 2(3), 8-14

Reigeluth, C.M \& Merrill, M.D. 1979. Classes of Instructional Variables. Educational Technology, March, 5-24.

Weiner, B. 1990. History of motivational research in education. Journal of Educational Psychology, 82 